\title{
Younger hanging wall rocks along the Vaikrita Thrust of the High Himalaya: A model based on inversion tectonics
}

\author{
Ashok K Dubey* and Surendra S Bhakuni \\ Wadia Institute of Himalayan Geology, 33 General Mahadev Singh Road, Dehra Dun - 248 001, INDIA \\ * To whom correspondence should be addressed.E-mail: akdubey@rediffmail.com
}

The High Himalayan rocks are divided into two main units, Munsiari Formation and Vaikrita Group. A geochronological study by Ahmad et al. (2000) revealed that the rocks of the Munsiari Formation, consisting of mainly granite gneisses have $\varepsilon_{\mathrm{Nd}}$ values from -23 to -28 similar to the Lesser Himalayan rocks occurring in the footwall of the Munsiari Thrust whereas the metasedimentary rocks of the Vaikrita Group show $\boldsymbol{\varepsilon}_{\mathrm{Nd}}$ values from -14 to -19 . The Sr isotope study revealed that the Vaikrita Group shows partial equilibration at $500 \mathrm{Ma}$ and the Munsiari Group has undergone Sr isotope homogenization at 1800Ma. In absence of marker horizons, displacements along the Munsiari and Vaikrita thrusts are still a matter of speculation. However, the Munsiari rocks occur as klippen in the Lesser Himalaya and the klippe to fenster method reveals that the maximum displacement along the klippen thrust in the Simla klippe is of the order of $\sim 40 \mathrm{~km}$ (Dubey and Bhat 1991). On the contrary, the trace of the Vaikrita Thrust is linear with occasional curves at oblique thrust ramps. Moreover, the Vaikrita Thrust has a weak geomorphic expression, which does not allow its mapping by satellite imagery. Mylonitization of the Vaikrita rocks can only be seen at the base but kyanite is uniformly distributed throughout the rock. The constituent minerals are coarse grained (size, 1-2 mm). In sharp contrast to these properties the constituent minerals of the Munsiari rocks are fine to medium grained (size, $<1 \mathrm{~mm}$ ), kyanite is occasionally present in small pockets, and mylonitization is a common feature throughout the sequence. Class 2 and Class 3 fold patterns are typical of Vaikrita rocks indicating ductile deformation whereas the Munsiari rocks exhibit mostly Class $1 \mathrm{C}$ folds characteristic of deformation at comparatively upper levels of the Earth's crust. Prominent stretching mineral lineation and presence of sheath folds suggest greater shear strain in the Munsiari rocks.

The metamorphic episodes in the area can be broadly classified into two: (i) pre-Himalayan metamorphism, and (ii) Tertiary Himalayan metamorphism. The pre-Himalayan metamorphism is now well established in several parts of the Himalaya. For example, a metamorphic event, prior to the emplacement of the early Palaeozoic granitoids was recognized in the SE Zanskar (NW Himalaya) by Pognante et al. (1990). The mineral assemblage indicated high $\mathrm{T}$ and high $\mathrm{P}$ conditions of crystallization $\left(\mathrm{T}=750 \pm 50^{\circ} \mathrm{C} ; \mathrm{P}=12.0 \pm 0.5 \mathrm{kbar}\right.$ ). The Vaikrita rocks underwent a higher grade of metamorphism (lower granulite facies) as compared to the Munsiari rocks and the metamorphic reconstitution took place at a depth of $\sim 30 \mathrm{~km}$ (Valdiya et al. 1999). The pre-Himalayan metamorphism was higher in metamorphic grade than the younger Himalayan metamorphism (Arita 1983).

Different phases of the Himalayan metamorphism are now known (Hodges and Silverberg 1988). The first Himalayan metamorphism was associated with the initial collision between India and Eurasia and the subsequent metamorphism was related to thrusting along the MCT. The second metamorphic event (i.e. Himalayan) occurred at similar or lower T and at lower P. The rocks show a normal metamorphism decreasing upward in metamorphic grade toward the overlying Tethyan sediments (Arita 1983).

The present study in the Garhwal-Kumaun High Himalaya help in understanding the occurrence of the younger hanging wall Vaikrita Group above the older footwall Munsiari Formation along the Vaikrita Thrust. The phenomenon is explained by an inversion tectonics based model where normal faulting and metamorphism was followed by thrusting characterized by displacement amount less than the displacement during the early normal faulting. The study takes into account the simple shear strains associated with the piggy back sequence of thrusting and pure shear strains associated with folding to explain the present structural set-up of the region.

\section{References}

Ahmad T, N Harris, M Bickle, H Chapman, J Bunbury and C Prince. 2000. Isotopic constraints on the structural relationships between the Lesser Himalayan Series and the High Himalayan Crystalline Series, Garhwal Himalaya. Bull Geol Soc Amer 112: 467-477

Arita, K. 1983. Origin of the inverted metamorphism of the Lower Himalayas, Central Nepal. Tectonophysics 95: 43-60

Dubey, AK and MI Bhat. 1991. Structural evolution of the Simla area, NW Himalayas: Implications for crustal thickening. J Southeast Asian Earth Sci 6: 41-53

Hodges KV and DS Silverberg. 1988. Thermal evolution of the greater Himalaya, Garhwal, India. Tectonics 7: 583-600

Pognante, U, D Castelli, P Benna, G Genivese, F Oberli, M Meier and S Tonarini. 1990. The crystalline units of the High Himalayas in the LahulZanskar region (north-west India): Metamorphic-tectonic history and geochronology of the collided and imbricated Indian plate. Geol Mag 127: $101-116$

Valdiya, KS, SKPaul, T Chandra, SS Bhakuni and RC Upadhyay. 1999. Tectonic and lithological characterization of Himadri (Great Himalaya) between Kali and Yamuna rivers, Central Himalaya. Himal Geol 20: 1-17 